лексического и грамматического материала. Это могут быть, как уже говорилось, блии-сочинения и письменные блии-переводы задания на перевод интернационализмов, грамматические упражнения на употребление страдательного залога, а также сочетание модальных глаголов с инфинитивом в страдательном залоге [1, с. 19, 36, 40].

Результатом применения вышеизложенных рекомендаций по обучению согласно представленной методике являются прикладные компетенции, позволяющие выпускникам применить полученные в процессе обучения знания и умения в области перевода в любой из сфер экономической деятельности человека и стать востребованными специалистами на конкурентом рынке труда. [1, с. 24].

\title{
Литература:
}

1. Парахина А. В. Пособие по переводу технических текстов с английского языка на русский: Для сред. спец. учеб. заведений. 3-е изд., доп. - М.: Высш. школа, 1982. С. 19-40.

2. Чернавина Л. И. Перевод научно-технической литературы. М.: ВЦП, 1978. С. 23-27.

3. Парфимович О. В. Доклад на тему «Медицинская геология одно из новых направлений научного перевода» на международной переводческой конференции «Translation Forum Russia» https://tconference.ru/itogi-translation-forum-russia-2019-2/ - СанктПетербург, 2019. С. 5-8.

4. Rudko G. Technogene As a New Stratigraphic Unit. Human Activity in Technogene. - Riga: LAP Lambert Academic Publishing, 2018. P. 1-3.

DOI https://doi.org/10.30525/978-9934-26-039-1-99

\section{ВИКОРИСТАННЯ ЕФЕКТИВНИХ ФОРМ І МЕТОДІВ ОН-ЛАЙН НАВЧАННЯ У ВИКЛАДАННІ ДИСЦИПЛІНИ «ПРАКТИЧНИЙ КУРС ОСНОВНОЇ ІНОЗЕМНОЇ МОВИ»}

\author{
Плахотнюк Н. П. \\ кандидат педагогічних наук,
}

старший викладач кафедри теоретичної і прикладної лінгвістики

Державного університету «Житомирська політехніка» м. Житомир, Украӥна

В умовах всесвітньої пендемії перед закладами вищої освіти постала проблема організації он-лайн навчання студентів. Серед пріорітетних 
завдань стоїть організація не просто процесу навчання майбутніх фахівців, а й створення сприятливих умов для розвитку навчальнопізнавальної діяльності, вмінь самостійно навчатися i здобувати необхідні знання та навички. Швидкими темпами відбувається формування мотиваційно-ціннісної складової структури особистості студента, основним пріорітетом якого $\epsilon$ самоосвіта і самовдосконалення. На жаль, як показує досвід, не всі студенти здатні до ефективного дистанційного навчання, адже воно передбачає збільшення часу на самостійну роботу.

Дистанційне навчання $є$ предметом вивчення як вітчизняних, так $\mathrm{i}$ зарубіжних науковців і має різні підходи до його визначення $[1 ; 2]$. Ми розуміємо його як форму організації навчального процесу, що грунтується на використанні традиційних і новітніх інформаційнокомунікаційних технологій, де взаємодія між викладачем і студентом здійснюється на відстані.

Навчальний процес студентів-філологів он-лайн відбувався за допомогою відеоконференцій на базі платформи Google Meet або Zoom, а також $з$ використанням групового чату (для кожної групи окремо), освітнього порталу університету, електронної пошти та гугл форм для виконання тестових завдань. Відеоконференції відбувались за розкладом традиційних пар, отже студенти мали постійний он-лайн зв'язок з викладачем. Перевага надавалась платформі Zoom, оскільки за допомогою функції «Сесійні зали» студенти мали можливість спілкуватись у маленьких групках і здійснювати парну роботу (складати діалоги, виконувати проблемно-пошукові завдання, проекти). Робота над довготривалими проектами відбувалась на протязі вивчення теми i iii результати були представлені по завершенні у вигляді он-лайн презентацій. Студенти мали показати рівень володіння лексико-граматичним матеріалом з теми, реалізацію дослідницько-пошукових навичок, вміння аналізу та синтезу. Представлений проект оцінювався не тільки викладачем, а й одногрупниками. Студенти виставляли бали за представлений проект іншим групам або парам за наступними критеріями: ступінь використання лексичних одиниць, креативність, навички говоріння, логічність викладу матеріалу, граматична коректність, досягнення цілей проекту. Запропоновані студентами обгрунтовані бали могли підвищити оцінку викладача за розроблений проект.

При викладанні дисципліни «Практичний курс основної іноземної мови» ефективним засобом дистанційного навчання виявився освітній портал університету. На порталі викладачі викладали навчальні матеріали для кожної групи і студенти могли їх використовувати як для 
самостійної підготовки, так і для он-лайн занять. Недоліком освітнього порталу є неможливість завантаження великого за обсягом матеріалу, в тому числі й відеоматеріалів. Ця проблема була вирішена за допомогою інтернет посилань, за якими студенти мали можливість переходити i виконувати необхідні завдання.

У процесі опанування навчальним матеріалом студенти і викладач також співпрацюють використовуючи груповий чат. У груповому чаті студенти і викладач спілкуються виключно іноземною мовою. У чаті майбутні фахівці мають можливість обмінюватись файлами, надсилати файлові повідомлення, задавати питання тощо.

Важливим компонентом дистанційного освітнього процесу $\epsilon$ оцінювання навчальних досягнень студентів. Вищезазначений процес здійснювався поточно і в кінці вивчення кожної теми за допомогою усного опитування, письмових завдань та тестів. Тестування дозволяє реалізувати функції контролю за досить невеликий проміжок часу, об’єктивно оцінити знання студентів, стимулювати навчально-пізнавальну діяльність шляхом заохочення до отримання вищого балу. Для успішного проведення тестового контролю викладачеві необхідно методично правильно і коректно скласти тести відповідно до вивченого матеріалу. Тестування за допомогою гугл форм $\epsilon$ ефективним методом оцінювання знань, оскільки є неупередженим і може одночасно застосовуватись для великої кількості студентів. Проте головним недоліком його є значні часові затрати з боку викладача.

Вищезазначені методи і форми дистанційного навчання $\epsilon$ необхідною умовою якісної системи сучасної освіти, забезпечують реалізацію освітніх потреб майбутніх фахівців, підвищують професійну мобільність i активність. Використання систематичного контролю i зворотного зв'язку забепечить створення ефективної дистанційної системи навчання.

\section{Література:}

1. Кухаренко В.М., Рибалко О. В., Сиротенко Н. Г. Дистанційне навчання та умови застосування. Харків. 2002. 320 с.

2. Бацуровська I.B. Технології дистанційного навчання у вищий освіті Електронний ресурс. Режим доступу: http://www.confcontact.com/ 20110225/pe4_samojl.htm. 